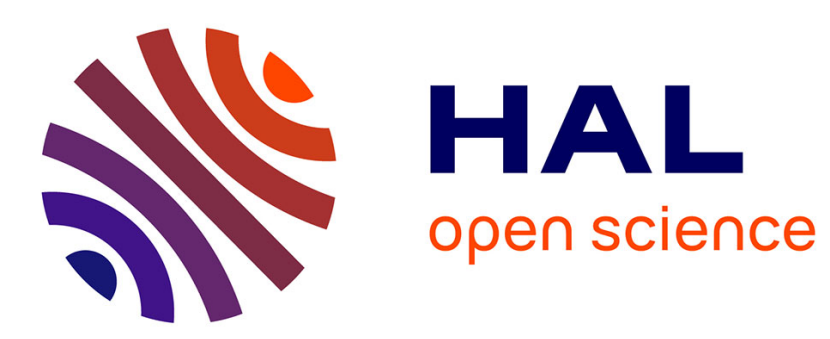

\title{
New biological model to manage the impact of climate warming on maize corn borers
}

Andrea Maiorano, Iacopo Cerrani, Davide Fumagalli, Marcello Donatelli

\section{To cite this version:}

Andrea Maiorano, Iacopo Cerrani, Davide Fumagalli, Marcello Donatelli. New biological model to manage the impact of climate warming on maize corn borers. Agronomy for Sustainable Development, 2014, 34 (3), pp.609-621. 10.1007/s13593-013-0185-2 . hal-01234806

\section{HAL Id: hal-01234806 \\ https://hal.science/hal-01234806}

Submitted on 27 Nov 2015

HAL is a multi-disciplinary open access archive for the deposit and dissemination of scientific research documents, whether they are published or not. The documents may come from teaching and research institutions in France or abroad, or from public or private research centers.
L'archive ouverte pluridisciplinaire HAL, est destinée au dépôt et à la diffusion de documents scientifiques de niveau recherche, publiés ou non, émanant des établissements d'enseignement et de recherche français ou étrangers, des laboratoires publics ou privés. 


\title{
New biological model to manage the impact of climate warming on maize corn borers
}

\author{
Andrea Maiorano - Iacopo Cerrani - Davide Fumagalli • \\ Marcello Donatelli
}

Accepted: 19 September 2013 / Published online: 30 October 2013

(C) INRA and Springer-Verlag France 2013

\begin{abstract}
Climate change can modify the development of insect pests and their impact on crops. The study of future impacts on maize remains relatively unexplored. Here we modeled the distribution and development of the maize borer Sesamia nonagrioides Lef. in Europe using a $25 \times 25 \mathrm{~km}$ grid. We studied the pest potential winter survival, distribution, and phenological development at three time horizons, 2000, 2030, and 2050, using the A1B scenario of the international panel on climate change (IPCC). A new model based on the lethal dose exposure concept was developed to simulate winter survival. Two approaches for the simulation of winter survival were compared: the first using air temperature only as weather input, named AirMS; the second taking into account the fraction of larvae overwintering in the soil, therefore considering also soil temperature, named SoilAirMS. The survival model was linked to a phenological model to simulate the potential development. Results show that soil temperature is an essential input for correctly simulating $S$. nonagrioides distribution. The SoilAirMS approach showed the best agreement (+537 grid cells), compared to the AirMS approach ( -2 , 039 grid cells). Nevertheless, the AirMS approach allowed identifying areas where the agronomic practice suggested for controlling $S$. nonagrioides should be considered ineffective. This practice consists in uprooting and exposing the stubble on the soils surface for exposing larvae to winter cold. The projections to 2030 and 2050 suggested an overall slight increase of more suitable conditions for the $S$. nonagrioides
\end{abstract}

\footnotetext{
A. Maiorano $(\bowtie) \cdot$ I. Cerrani $\cdot$ D. Fumagalli

European Commission DG Joint Research Centre,

MARS - AGRI4CAST, Institute for Environment and Sustainability,

via Fermi, Ispra, VA, Italy

e-mail: maiorano.andrea@gmail.com

M. Donatelli

Consiglio per la Ricerca e sperimentazione in Agricoltura,

Centro di ricerca per le colture industriali, Bologna, Italy
}

in almost all the areas where it develops under the baseline. In these areas, $S$. nonagrioides could become a new insect pest with a potential strong impact on maize. This is the first attempt to provide extensive estimates on the effects of climate change on $S$. nonagrioides distribution, development, and on possible management changes.

Keywords Process-based models · Spatialized simulations · Insect pest $\cdot$ Winter survival model $\cdot$ Phenological model . Climate change $\cdot$ Potential distribution $\cdot$ Sesamia nonagrioides

\section{Introduction}

The Mediterranean corn borer (Sesamia nonagrioides Lef.) is one of the most important maize borers in Europe (Photo 1). Besides maize, its range of host plants is broad, including sorghum, millet, rice, sugar cane, grasses, melon, asparagus, palms, banana, and the ornamental plant Strelitzia reginae (Eizaguirre and Fantinou 2012 and references therein). Gillyboeuf et al. (1994) reported that its distribution and population levels are primarily determined by its sensitivity to sub-zero winter temperatures. In Europe, the 45th parallel has been indicated as its northern limit (Gillyboeuf et al. 1994; Eizaguirre and Fantinou 2012), and its spread and development have been mainly reported from the areas where it is considered an important pest. These areas include the coastal regions of the Mediterranean basin (up to four generations per year) and of the Atlantic coasts up to the coasts of south western France (one or two generations) (Gillyboeuf et al. 1994; Eizaguirre and Fantinou 2012). Nevertheless, other sources of information suggest that the limits for the Mediterranean corn borer spread could be around the 48th49th parallel. These sources of information include, e.g., agricultural extension literature like the French Bulletin de 
santé du vegetal—Pays de la Loire (http://www.draaf.pays-dela-loire.agriculture.gouv.fr/Derniers-Bulletins-de-Sante-du) and web information facilities like the Carnet du Lépidoptériste Français (http://www.lepinet.fr).

The Mediterranean corn borer develops through four main stages: egg, larvae, pupae, and adult, and it overwinters as a diapausing larva in maize stalks and roots (Gillyboeuf et al. 1994). Photoperiod has been reported as the crucial factor for the termination of diapause (Fantinou et al. 2002). Mediterranean corn borer diapause termination starts when photoperiod $\geq 12 \mathrm{~h}$ and larvae pupate after around 48 days. Temperature is also important as it was reported to be synergistic in enhancing diapause development (Fantinou et al. 2002).

Different management strategies have been suggested for the control of the Mediterranean corn borer populations. They include agronomic measures like the uprooting and exposing the stubble on the soil surface for exposing the diapausing larvae to the winter cold temperatures, mating disruption techniques, transgenic maize expressing Bacillus thuringiensis Berliner, and chemical control (Gillyboeuf et al. 1994; Albajes et al. 2002; Farinós et al. 2011). Furthermore, diapause induction can be influenced by maize cycle with consequences on population levels (Eizaguirre et al. 2007).

Insects are poikilotherms (i.e., body temperature varies along with that of the environmental temperature), hence their development, geographic distribution, and population density are strongly influenced by temperature. As a consequence, a warming climate has the potential to significantly modify the actual distribution and development of insects, including agricultural insect pests, with unknown consequences in agricultural systems (Gutierrez et al. 2010). Insect pest simulation models allow the estimation of the potential effects of a warming climate on insects based on their known physiological responses to specific weather factors (Régnière 2009). This can be helpful for estimating the impact of such changes also on management strategies and techniques.

No study has estimated yet the potential effects on the Mediterranean corn borer spread, development, and

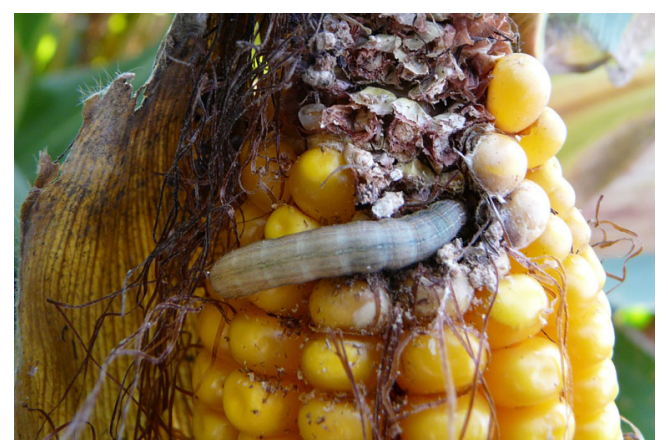

Photo 1 Sesamia nonagrioides larva tunneling in a maize ear management in Europe under present and near future climate scenarios. The objectives of this paper consequently are as follows:

- To analyze the role of temperature in the potential distribution and development of the Mediterranean corn borer in Europe

- To consider the potential impact on agro-management under current and near future climate scenario.

\section{Materials and methods}

The work was carried out in five phases: (1) the current distribution of the Mediterranean corn borer in Europe was estimated using data and information from different sources, (2) an original winter survival model was developed based on the Mediterranean corn borer cold tolerance, (3) a phenological model was calibrated for the Mediterranean corn borer, (4) the models were applied in spatialized simulation runs in Europe, and (5) a method for mapping the Mediterranean corn borer distribution was defined.

\subsection{Current distribution records}

Records of reliable experimental data assessing the presence of insect pests usually come from limited areas where the insect is considered an important biotic adversity. Therefore, the present known distribution of the Mediterranean corn borer was estimated using a diversity of sources of information. Sources included scientific literature, technical literature, internet-based information facilities, and agricultural extension service publications. Scientific and technical literature was used to identify the areas where the Mediterranean corn borer is considered an insect pest. These areas included the following:

- France: Aquitaine, Languedoc-Roussillon, MidiPyrénées, Pays de la Loire, Rhône-Alpes (Gillyboeuf et al. 1994; Albajes et al. 2002; Leniaud et al. 2006)

- Germany: South West (ENDURE 2010)

- Greece: Central Greece, Macedonia, Peloponneso, Thessaly (Albajes et al. 2002; Dimou et al. 2007; Andreadis et al. 2011; Farinós et al. 2011)

- Italy: Campania, Lazio, Po Valley, Apulia, Sardinia, Sicily (Boselli 1959; Nucifora 1966; Porcelli and Parenzan 1993; Avantaggiato et al. 2003; ENDURE 2010; Germinara and Rotundo 2011)

- Portugal: Alentejo, Portugal Centro (Mendes 1913; Figueiredo and Araujo 1990)

- Spain: Andalucia, Aragon, Asturias, Castilla-LaMancha, Catalunia, Extremadura, Galicia, Navarra (Delgado de 
Torres 1929; Albajes et al. 2002; Novillo et al. 2003; Leniaud et al. 2006; Velasco et al. 2007)

- Turkey: Aegean Region, Mediterranean Region (Kavut 1987; Bayram et al. 2007)

The other areas where the presence of the Mediterranean corn borer has been reported were identified through the following secondary sources of information: the Global Biodiversity Information Facility (www.gbif.org), the Carnet du Lépidoptériste Français (CLF, http://www.lepinet.fr), the initiative Plantwise by CABI (http://www.plantwise.org), and the Pan-European Species directories Infrastructure (http:// www.eu-nomen.eu/). These secondary sources of information give information about the presence or not of the insect at the country level, with the exception of the CLF website giving information at a regional level for France. The current distribution records were used to define the Mediterranean corn borer plausible distribution map. Given that the distribution records were not homogeneously distributed in Europe, the mapping of the observed distribution was done as follows: the records from the scientific and technical literature listed above and from the CLF website were arbitrarily mapped at NUTS 2 level (i.e., European Nomenclature of territorial units for statistics - http://epp.eurostat.ec.europa.eu/portal/page/portal/ nuts_nomenclature/introduction), and the records from other sources were mapped at the country level.

\subsection{Winter survival model}

The winter survival model is based on the dose/response concept used in toxicology to determine the toxicity, for instance, of pesticides. This is usually done by testing the binomial response (i.e., death/no death) of an organism to a chemical under various concentrations (i.e., "doses") and then comparing the concentrations at which there is a response (Vincent 2013). The lethal dose (LD) indicates the dose (exposure) that kills a defined threshold percentage of the population. The thresholds that are usually used to compare the dose effects are $50 \%\left(\mathrm{LD}_{50}\right), 75 \%\left(\mathrm{LD}_{75}\right)$, or $90 \%\left(\mathrm{LD}_{90}\right)$ of insect pest population killed by the chemical.

In the analogy of the winter survival model:

- the air and/or soil temperature is the "chemical";

- the time of exposure (hours) is the "dose", and the expression "lethal time" (LT) was used instead of "lethal dose";

- $\quad 90 \%$ of insect population mortality $\left(\mathrm{LT}_{90}\right)$ is the reference threshold used to estimate the effect of time exposure.

The effect of a specific harmful temperature is assumed to be additive only if the same temperature (or a lower temperature) is registered on consecutive hours. Hence, the time of exposure is calculated as the sum of consecutive hours at a specific harmful temperature. In order to calculate the time of exposure of a specific temperature, input air and/or soil temperature are approximated by nearest integer. The exposure to a harmful temperature increases the time of exposure to that temperature and the one to higher temperatures. The following two examples clarify the rationale of the calculation of the time of exposure:

- Example A: sample temperatures: $-2,-2,-4,-4,-3{ }^{\circ} \mathrm{C}$. The exposure to $-2{ }^{\circ} \mathrm{C}$ is $5 \mathrm{~h}$, the one to $-3^{\circ} \mathrm{C}$ is $3 \mathrm{~h}$, and the one to $-4{ }^{\circ} \mathrm{C}$ is $2 \mathrm{~h}$;

- Example B: sample temperatures: $-2,-2,-4,-2,-3{ }^{\circ} \mathrm{C}$. The exposure to $-2{ }^{\circ} \mathrm{C}$ is again $5 \mathrm{~h}$, while the exposure to 4 and $3{ }^{\circ} \mathrm{C}$ is just $1 \mathrm{~h}$. The exposure to $-3{ }^{\circ} \mathrm{C}$ is not $2 \mathrm{~h}$ because the sequence of temperatures $\leq 3{ }^{\circ} \mathrm{C}$ is interrupted by $1 \mathrm{~h}$ at $-2{ }^{\circ} \mathrm{C}$.

The data source used for the development of the survival model consisted of data about mortality (\%) of diapausing cold-acclimated larvae of Mediterranean corn borer following exposure to cold temperatures (reference temperature values $-15,-10.8,-4,-2$, and $0{ }^{\circ} \mathrm{C}$ ) and different time of exposure (from 2 to $64 \mathrm{~h}$ ) obtained by Gillyboeuf et al. (1994) and Andreadis et al. (2011). Data from Gillyboeuf et al. (1994) showed that at $0{ }^{\circ} \mathrm{C}$ there was almost no mortality difference between the different time exposures. Since these data showed that a relationship between temperature, time of exposure, and mortality was evident at temperatures $\leq-2{ }^{\circ} \mathrm{C}$, this temperature was fixed as a threshold for calculating mortality, while the average mortality at $0{ }^{\circ} \mathrm{C}$ was used in the model as total intrinsic diapausing larvae mortality $\left(M_{\text {int }}\right)$. According to Andreadis et al. (2011), at $10.8^{\circ} \mathrm{C}$ the $90 \%$ of the population dies in $2 \mathrm{~h}$, and at $-15^{\circ} \mathrm{C}$ no individual can survive after even a short time exposure ( $5 \mathrm{~min}$ ). Since $5 \mathrm{~min}$ is a very short time exposure, we assumed that at $-15{ }^{\circ} \mathrm{C}$ the $90 \%$ of the population dies in around $0.9 \times 5 \mathrm{~min}$ that is $3.6 \mathrm{~min}$. Probit analysis (Finney 1971) was performed for estimating the $\mathrm{LT}_{90}$ at -4 and $-2{ }^{\circ} \mathrm{C}$. Probit analysis is usually used in toxicology to analyze dose-response or binomial response experiments. The response is always binomial (e.g., death/no death) and the relationship between the response and the various concentrations is sigmoidal. Probit analysis acts as a transformation from sigmoid to linear (using a cumulative normal probability distribution) and then runs a regression on the relationship (Vincent 2013). Following results of probit analysis, a thermal death time curve (TDTC) representing $\mathrm{LT}_{90}$ at any temperature $\leq-2{ }^{\circ} \mathrm{C}$ was developed using two linear models (see "Survival and phenological development modeling" section).

At each time step, if temperature is below the $-2{ }^{\circ} \mathrm{C}$ threshold, the actual time of exposure (h) to harmful temperatures is calculated. The TDTC is used to calculate the proportion of $\mathrm{LT}_{90}\left(\mathrm{pLT}_{90}\right)$ equal to the actual time of exposure divided by $\mathrm{LT}_{90}$ at any harmful temperature. The final output of the winter survival model is the proportion of total mortality at 
time $i\left(M_{i}\right)$. This is calculated through the relationship existing between $\mathrm{pLT}_{90}$ and $M_{i}$. This relationship was modeled using the logarithmic function:

$M_{i}=0.9 *\left(a * \ln \left(b * p \mathrm{LT}_{90}+1\right)\right)$

where 0.9 is an adjustment factor for scaling $M_{i}$ to a $0-1$ mortality scale, and $a$ and $b$ are fitting parameters obtained by optimizing Eq. (1) to the observed mortality data from Gillyboeuf et al. (1994) and Andreadis et al. (2011) (leastsquares method, Microsoft Excel ${ }^{\circledR}$ Solver). The function is limited by a plateau fixed at $M_{\max }=1$ which is the maximum total mortality.

Thus, at each time step $i$ during diapause, if hourly temperature is $\leq-2{ }^{\circ} \mathrm{C}, M_{i}$ is re-calculated and the following rule is applied:

$$
\text { if } M_{i}>\left(S_{0}-S_{i-1}\right), \quad \text { then } S_{i}=S_{0}-M_{i}, \quad \text { else } S_{i}=S_{i-1}
$$

where $S_{0}$ is the relative starting level of population (given by $\left.1-M_{\text {int }}\right), S_{i}$ are actual survivors, and $S_{i-1}$ are survivors at time $i-1$. In this way, it is assumed that sub-zero temperatures operate a negative selection on the population: the proportion of individuals that survive to a specific time exposure and temperature are killed by higher time exposure and/or lower temperatures. Gillyboeuf et al. (1994) estimated that around $70-85 \%$ of Mediterranean corn borer larvae overwinter in maize residues above the soil surface and the remaining larvae in roots (up to $10 \mathrm{~cm}$ below the soil surface). Consequently, two modeling solutions were implemented and compared for the simulation of winter survival: the first one (AirMS) using as input only air temperature, and the second one (AirSoilMS) using air and soil temperature. Soil temperature in the first $10 \mathrm{~cm}$ was estimated using the model component UNIMI.SoilT coupled to the UNIMI.SoilW component (http://agsys.cra-cin.it/tools/) for simulating water balance, being soil water content a needed input to estimate soil temperature. Only one synthetic soil profile, representing a loam soil in flat land, was simulated. Based on Gillyboeuf et al. (1994), it was assumed that $20 \%$ of diapausing population was overwintering in roots, and $80 \%$ in maize stems above soils surface. In agreement with the findings of Gillyboeuf et al. (1994), the development model was started if at the end of diapause survivors were $\geq 5 \%$.

\subsection{Phenological model}

The data source used for the development model consisted of mean development time (days) of immature stages of Mediterranean corn borer at constant temperatures found in Hilal (1981), López et al. (2001), and Fantinou and Chourdas (2005). Data found in Fantinou et al. (2004) were used to determine the time needed to complete the pre-oviposition period of the adult stage. The phenological model is based on the rate summation method detailed by Curry and Feldman (1987). This method is based on the concept that development rates are additive for changing temperatures, and it uses as the development rate the reciprocal of the mean development time for each constant temperature. Development rates for completing the different stages were normalized by dividing the observed response to a given temperature by the maximum development rate in order to obtain a common temperature response profile for all the stages. In this way, multiplying the reciprocal of the days required to complete a generation at the optimum temperature, the rate summation at any instant is the fraction of the mean process time completed at that instant. As an equation (from Curry and Feldman 1987):

$d_{t}=\frac{1}{n} \sum_{i=1}^{n_{t}} r\left(T_{i}\right)$

where $d_{t}$ is the fraction of mean development that has occurred after $t$ days, $n$ is the number of increments in a day (in this work-24h), $n_{t}$ is the number of increments in $t$ days, $r$ is the temperature-dependent developmental rate calculated at temperature $T_{i}$, and $i$ is the actual time step.

Differently from other works where the development of maize insect borers, including the Mediterranean corn borer, was simulated using a linear response to temperature (e.g., López et al. 2001; Trnka et al. 2007; Diffenbaugh et al. 2008), in this work a non-linear response was chosen to properly account for above optimum temperatures. Non-linear response model must be preferred whenever simulations must cover temperatures over the full range of physiological activity, as in the case of studies under warming climate (Régnière and Logan 2003; Maiorano et al. 2012). The following beta function by Yan and Hunt (1999) was used to fit the normalized developmental rates:

$f(T)=\left(\left(\frac{T(h)-T_{\min }}{T_{\mathrm{opt}}-T_{\min }}\right)\left(\frac{T_{\max }-T(h)}{T_{\max }-T_{\mathrm{opt}}}\right)^{\left(\frac{T_{\max }-T_{\mathrm{opt}}}{T_{\mathrm{opt}-T_{\min }}}\right)}\right)^{c}$

where $T(h)$ is the hourly temperature, $T_{\min }$ is the minimum extreme temperature for development, $T_{\max }$ is the maximum extreme temperature for development, $T_{\text {opt }}$ is the optimum temperature of development, and $c$ is the shape parameter. Parameters $T_{\text {min }}, T_{\text {opt }}$, and $c$ were optimized to fit the normalized developmental rates (least squares method, Microsoft Excel $^{\circledR}$ Solver). Since experimental data within the feasible temperature range for $T_{\max }$ were not found available in literature, the constraint imposed to the optimization was fixing $T_{\max }$ to the value of $40{ }^{\circ} \mathrm{C}$, based on the values estimated by López et al. (2001).

Following information found in literature (Fantinou et al. 2002), the phenological model was started (i.e., biofix) after 
that scotophase (dark phase of photoperiod) was $<12 \mathrm{~h}$. The scotophase was estimated using the SolarRadiation model component (http://agsys.cra-cin.it/tools/) with latitude and day of year as input.

\subsection{Climate scenarios}

A dataset of weather data on scenarios of future climate, suitable for use with biophysical models, has recently become available from the European Commission JRC, derived from the ENSEMBLE scenarios, and covering Europe with a grid of $25 \times 25 \mathrm{~km}$ (Donatelli et al. 2012). A maize crop mask based upon the same grid was used to limit the study to the areas where maize is currently cultivated in Europe. The maize crop mask is the one used at the European Commission JRC for scenarios studies (e.g., AVEMAC Project, Donatelli et al. 2012). One realizations of the Intergovernmental Panel on Climate Change (IPCC) was used as the input of the analysis. This was based upon the emission scenario A1B (i.e., scenario of a more integrated world with a balanced emphasis on all energy sources) from the runs of the global circulation model ECHAM5-R3, bias-corrected and downscaled from the original ENSEMBLES data set by the HIRHAM5 RCM regional climate model to a $25-\mathrm{km}$ grid resolution (Dosio and Paruolo 2011). The winter survival and phenological simulations were performed referring to the time horizons 2030 and 2050 in comparison to the baseline of 2000 on a sample of 10 synthetic years for each time horizon. The aim was to estimate potential distribution and development in the future temperature regime compared to current (baseline-2000) conditions.

\subsection{Potential environmental suitability and geographic distribution}

For each implemented modeling solutions (AirMS and AirSoilMS), the Mediterranean corn borer potential environmental suitability was estimated according to winter survival and phenological development. For each grid, a simulated year was considered suitable to Mediterranean corn borer population development if the population survived to winter conditions (see "Winter survival model" section) and if the survived population was able to develop at least one generation (see "Phenological model" section). Finally, the potential environmental suitability of each grid was estimated according to a minimum threshold of number of suitable years out of the 10 simulated for each grid. Different potential environmental suitability were evaluated according to the different minimum threshold considered (from 1 to 10), where threshold $=1$ meaning Mediterranean corn borer population surviving in areas characterized by persisting adverse years and able to develop in infrequent favorable years ( 1 in this case), and threshold $=10$ meaning Mediterranean corn borer population surviving and developing only in areas where optimal conditions for survival and development appear every years. The application of this method to a grid $(25 \times 25 \mathrm{~km})$ covering Europe (coastal regions of Turkey included) gave as a result 10 potential geographical distribution (one for each threshold) of the Mediterranean corn borer. The obtained potential distributions were checked by comparing them to the observed distribution (see "Current distribution records" section).

\subsection{Model implementation and software technology}

The models were implemented in a model component (MIMYCS.Borers) composed of discrete model units of fine granularity. MIMYCS.Borers is one of the models of the framework MIMYCS (Maize Infection and MYcotoxin contamination Simulator-FP7 Marie Curie Project) developed at the European Commission JRC for the simulation of mycotoxin contamination in grain maize. Models of the MIMYCS framework were developed using the software componentoriented paradigm which allow the reusability of them either as standalone models or composed with other models for the development of new modeling solutions. The component architecture was the one proposed by Donatelli and Rizzoli (2008). The MIMYCS components can be easily re-used in any platform based on Microsoft ${ }^{\circledR}$.NET platform and they were implemented as modeling solutions for the BioMA platform of the European Commission (http://bioma.jrc.ec. europa.eu/). A modeling solution is a discrete simulation engine where different models are selected and integrated in order to carry out simulations for a specific goal. The modeling solution used in this work is composed by the components UNIMI.SoilT and UNIMI.SoilW (http://agsys. cra-cin.it/tools/) for the estimation of soil daily temperature, AirTemperature (Donatelli et al. 2010) for the estimation of hourly temperature, SolarRadiation (Donatelli et al. 2006) for the estimation of scotophase, the survival component presented in this paper, and the component MIMYCS.Borers for the simulation of development times. Figure 1 shows the modeling solution component diagram and the relationship between the components. Inputs needed are daily air temperatures and rainfalls. Daily rainfalls are used by the component UNIMI.SoilW for simulating water balance. Outputs are percentage of potential survivors, potential phenological development, and potential number of generations per year.

\section{Results and discussion}

\subsection{Current distribution records}

Figure 2 shows the map of the probable current distribution of the Mediterranean corn borer in Europe according to the 
Fig. 1 Software component diagram of the Mediterranean corn borer survival and phenological modeling solution

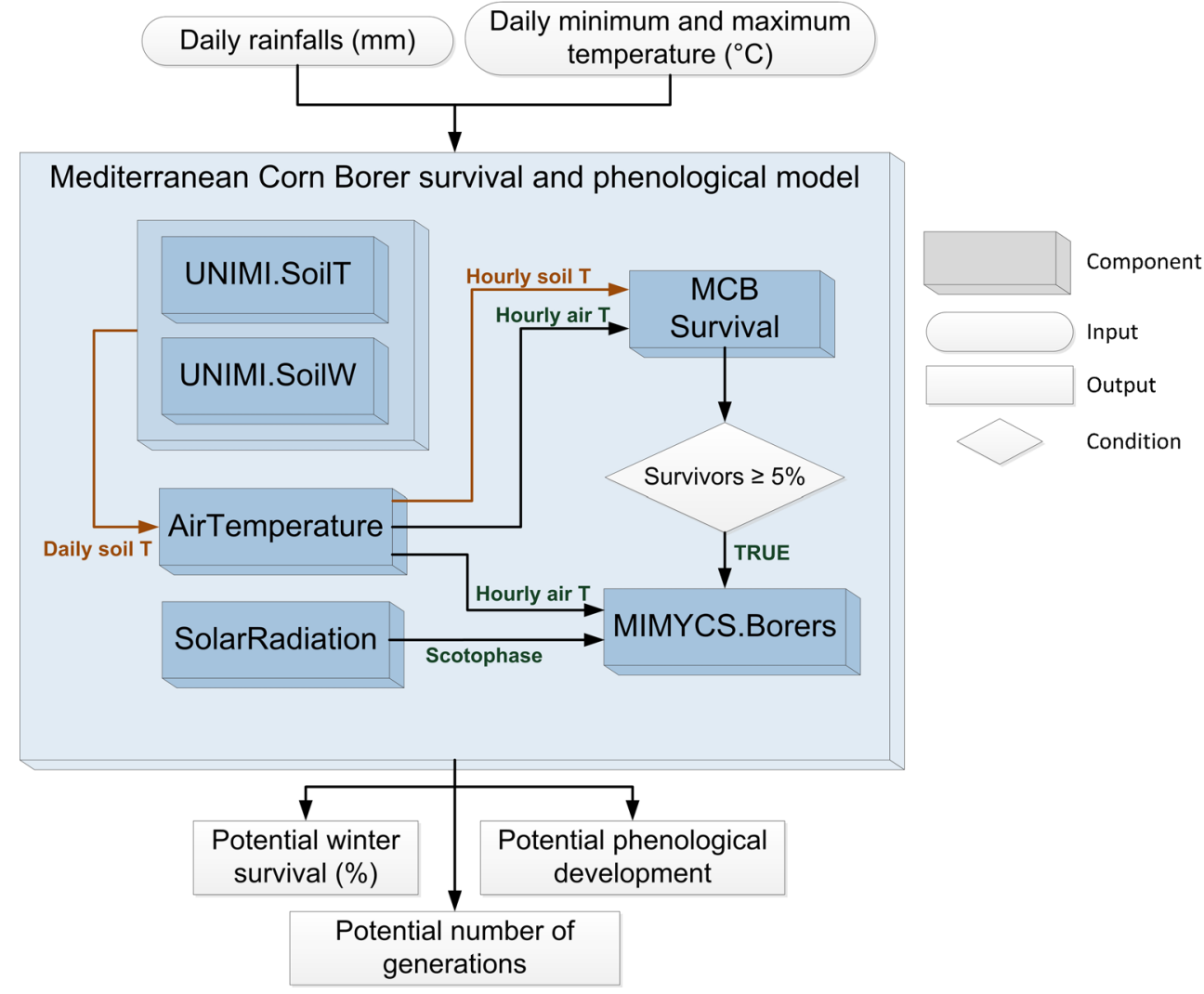

sources of information found in literature and the World Wide Web. The Mediterranean corn borer is spread in all the coastal regions of the Mediterranean basin and of the Atlantic coasts up to the French region of Pays de la Loire. In France, the CLF website reports the presence of the Mediterranean corn borer also in Corse, and in the Regions of Basse-Normandie, Centre, and Picardie (49th parallel) which are well above the 45th parallel and which was reported as the northern limit of the Mediterranean corn borer. Nevertheless, it must be pointed out that in these regions the Mediterranean corn borer is not a pest of agricultural interest. Information was found about the presence of the Mediterranean corn borer in the Balkans region, in Bulgaria, and in Austria. However, this information is only at the country level as no more specific and precise source of information was found. A report by the Endure network (ENDURE 2010) reports the presence of the Mediterranean corn borer also in southwestern Germany and in the Po Valley in Northern Italy. In these regions, the Mediterranean corn borer is reported to be a pest of low importance.

\subsection{Survival and phenological development modeling}

Figure 3 shows the thermal death time curve for $90 \%$ mortality (Fig. 3a), the curve of proportion of total mortality (Fig. 3b), a winter survival model output sample (Fig. 3c), and the development rates (Fig. 3d), together with the modeled response, estimated parameters, and the indicators of goodness of fit (the root mean square error-RMSE - and the $R^{2}$ ).

The thermal death time curve (Fig. 3a) is characterized by a point of strong discontinuity at $-4{ }^{\circ} \mathrm{C}$ : this temperature has been reported to be starting point of freezing of extra-cellular ice nucleating agents (INA) present in insect species classified as freeze tolerant, like the Mediterranean corn borer (Bale and Hayward 2010; Andreadis et al. 2011): the presence of INA gives the insect the ability to adapt to sub-zero temperatures, but the formation of ice causes damaging deformation to cells (Mazur 1984).

The resulting winter survival model is:

$$
\begin{aligned}
& \text { if } T_{i}>-2{ }^{\circ} \mathrm{C} \quad \text { No mortality } \\
& \text { if } T_{i} \leq-2{ }^{\circ} \mathrm{C} M_{i}=0.9 * 0.201 * \ln \left(123.14 * \frac{h_{\exp }\left(T_{i}\right)}{\left(c * T_{i}+d\right)}+1\right)
\end{aligned}
$$

where $T_{i}$ is the input temperature at time step $i, h_{\exp }\left(T_{i}\right)$ is the exposition (h) at temperature $T_{i}$ at time step $i,\left(c^{*} T_{i}+d\right)$ is the linear model for calculating the hours of exposure needed for $90 \%$ mortality at $T_{i}$ (if $-4{ }^{\circ} \mathrm{C} \leq T_{i} \leq-2{ }^{\circ} \mathrm{C}$ then $c=79.25, d=322.5$; if $T_{i} \leq-4{ }^{\circ} \mathrm{C}$ then $\left.c=0.4952, d=7.4444\right)$.

The total number of days required to complete one generation at the optimum temperature resulted equals to 40 days 
Fig. 2 Mediterranean corn borer observed distribution. Red areas (NUTS 2 level) are areas where the Mediterranean corn borer is considered an important pest. Yellow areas (NUTS 2 level) are regions where the presence of the insect was reported and it is considered a pest of low importance. Gray areas (NUTS 0 level) are countries where the presence of the insect was reported at the country level. NUTS European nomenclature of territorial units for statistics

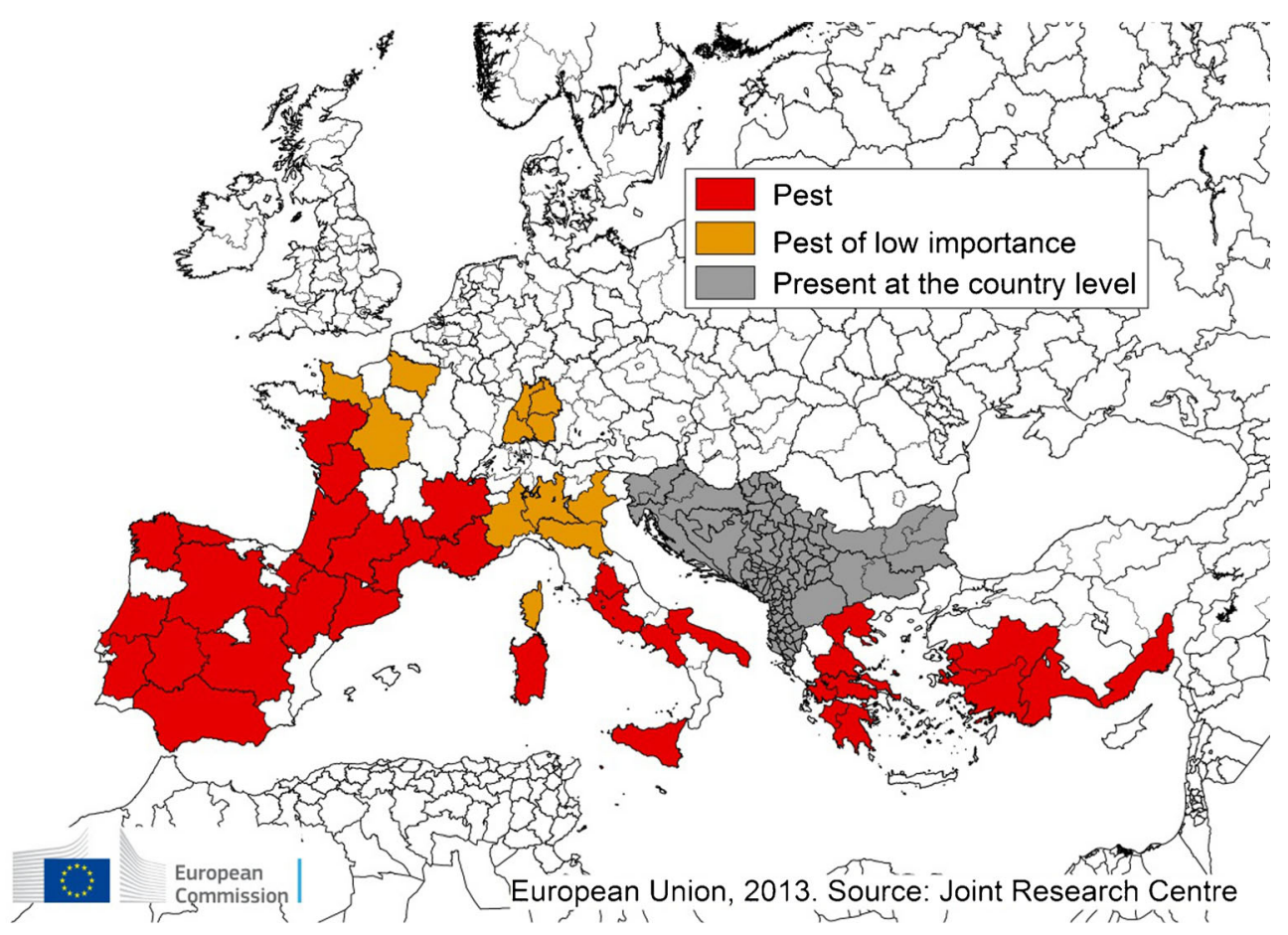

which means a relative growth rate of $0.025 \mathrm{day}^{-1}$. Following optimization, the optimal values for the Eq. 4 parameters were as follows: $T_{\min }=7.7, T_{\mathrm{opt}}=30.7, T_{\max }=40$ (fixed value), and $c=1.9$.

\subsection{Potential distribution under actual and future scenarios}

Between the simulated 10 potential distributions (see "Potential environmental suitability and geographic distribution" section) under baseline scenario, only the ones obtained applying the minimum thresholds of 3 and 8 years (out of 10 simulated) are shown in Fig. 4.

In order to compare the observed vs. simulated distribution, the regional data of observed distribution were converted to grids using the same grid described in "Climate scenarios" section. The difference between the observed (obs) and the simulated (sim) number of grid cells was described according to the absolute error $(\mathrm{AE}=|\mathrm{obs}-\mathrm{sim}|)$. The observed distribution accounted for 2,663 grid cells. As expected, under the 2000 scenario, none of the potential distributions estimated using the AirMS approach were adherent to the observed distribution. Using this approach and the threshold $=8$, the distribution was quite underestimated ( $\mathrm{AE}=2,039)$. Even hypothesizing a good resistance of Mediterranean corn borer populations to recurrent unfavorable conditions (threshold $=3$ ), the predicted distribution is very limited compared to the observed one $(\mathrm{AE}=1,536)$. This modeling approach does not consider the fraction of population overwintering in the soil which provides an effective thermal buffer against very low air temperatures. This is the reason of the wider area covered by the potential distributions obtained using the SoilAirMS approach. The potential distribution estimated by AirMS includes mainly some of the Mediterranean and Atlantic coastal regions of Europe which are already known from literature to be areas with high population levels of Mediterranean corn borer with important impacts on cultivated maize. Even though the distribution simulated using the AirMS approach is not adequate for representing the general potential distribution of the Mediterranean corn borer, it gives information about the insect winter survival that are interesting from an agronomic management point of view. The potential distribution simulated by this approach shows the areas where air temperature alone can guarantee Mediterranean corn borer survival. In these areas, the agronomic practice that was suggested for controlling the Mediterranean corn borer should be considered ineffective. The practice was uprooting and exposing the stubble on the soils surface for exposing larvae to winter cold (Gillyboeuf et al. 1994). These areas are expected to increase between 2000 and 2050, and most of the increase can be observed in the Spanish region of Extremadura and in Southern Italy (Fig. 5).

Results coming from the SoilAirMS approach are more interesting because they take into account also soil temperature. Hence, it is a closer-to-reality representation of the Mediterranean corn borer winter survival system. Considering this approach, when the threshold is set equal to 3 years, the potential distribution of the 2000 scenario is largely overestimated and spread to areas where the Mediterranean corn borer has never been reported including Southern England, Belgium, the Netherlands, Central, Northern and 
Fig. 3 Mediterranean corn borer survival and development rates curves. a Thermal death time curve indicating the required exposure (h) to cause $90 \%$ of mortality. Exposure a: $h=79.25 T+322.5$. Exposure b: $h=0.4952 T+7.4444$. b Proportion of mortality ( $1=100 \%$ total mortality) as a function of proportion of time for $90 \%$ mortality $\left(\mathrm{LT}_{90}\right)$. Equation: $M_{i}=0.9 * 0.201 * \ln \left(123.14 * \mathrm{pLT}_{90}+1\right)\left(\mathrm{RMSE}=0.12, r^{2}=0.77\right)$. Dotted line is the maximum proportion of mortality. c Winter survival model sample output for a site in Northern Italy, year 2008. Blue solid line is the hourly temperature $>-2{ }^{\circ} \mathrm{C}$. Red solid line is the hourly temperature $\leq-2{ }^{\circ} \mathrm{C}$. Red dotted line indicates the threshold for calculating mortality during diapause $\left(-2{ }^{\circ} \mathrm{C}\right)$. The black solid line indicates the proportion of population surviving at time $i(\mathrm{Si})$. d Relationship between temperature and normalized development rates (RMSE $\left.=0.06, r^{2}=0.97\right), T_{\min }=7.7$, $T_{\mathrm{opt}}=30.7, T_{\max }=40$ (fixed value), and shape parameter $c=1.9$

Western Germany, Northern and Eastern France, Serbia, and Bulgaria $(\mathrm{AE}=1,808)$. The potential distribution is progressively reduced with the increase of the threshold. These results are in agreement with the reported high sensitivity of Mediterranean corn borer population to thermal stresses (Gillyboeuf et al. 1994). If compared to the observed distribution, the better agreement of higher thresholds indicates that even in areas where years with unfavorable survival conditions occur just occasionally, the Mediterranean corn borer populations could be seriously affected and future development compromised. The best agreement with the observed distribution was observed when the threshold was equal to 10 years out of 10 simulated (data not shown). Nevertheless, a lower threshold was preferred that is taking into account that the Mediterranean corn borer population could survive to few occasional unfavorable years. It must be noticed that in this work each run of simulation was independent from the others, that is, the 10 years were treated independently and not as a time series, meaning that possible cumulative effects of consecutive positive (or negative when choosing lower thresholds) years on the Mediterranean corn borer population were not considered. Furthermore, the area covered by distributions obtained using slightly lower thresholds than the 10-year threshold (e.g., 8 or 9), was just slightly higher than the 10 threshold one. Considering the intrinsic spatial distortions included in the use of a $25 \times 25 \mathrm{~km}$ grid (Donatelli et al. 2012), it was considered reasonable using a threshold slightly lower than 10 . Therefore, it was decided to use a threshold of 8 for this study that is considering that Mediterranean corn borer population can survive to two unfavorable years out of 10 . When the threshold is set equal to 8 , the estimated potential distribution appears very close to the observed one $(\mathrm{AE}=537)$ with the exception of Southern England and Benelux (not included in the observed distribution). Results of simulations seem to indicate that in the Balkans the Mediterranean corn borer is distributed only in the coastal regions. From the literature search, it was only possible to determine the presence of the insect at the national level, but not its distribution at finer level. It must be pointed out that this work focuses on the potential distribution based on
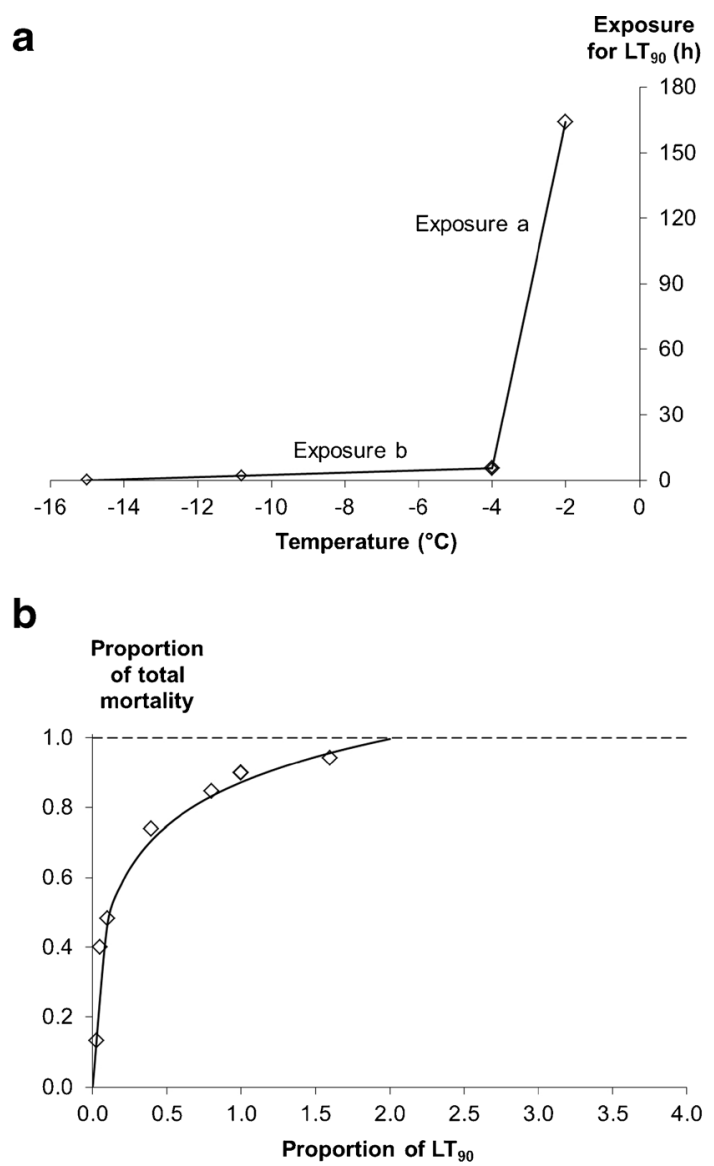

C

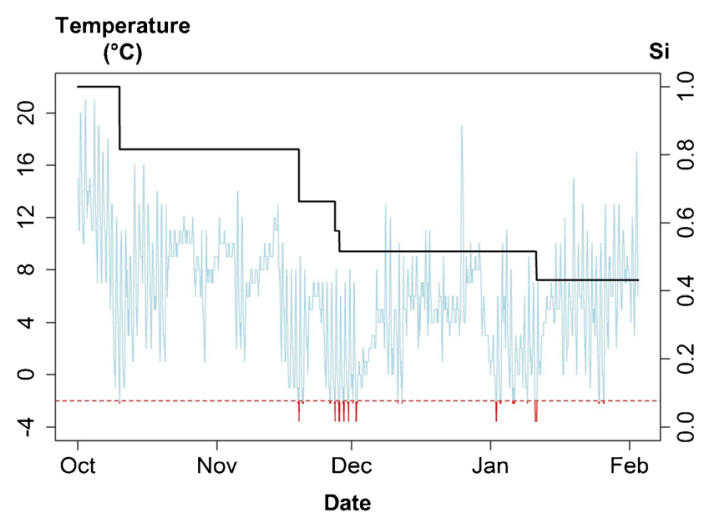

d

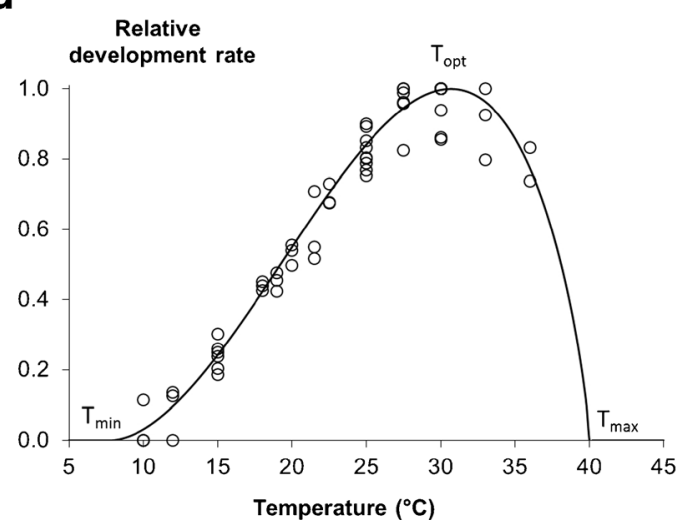




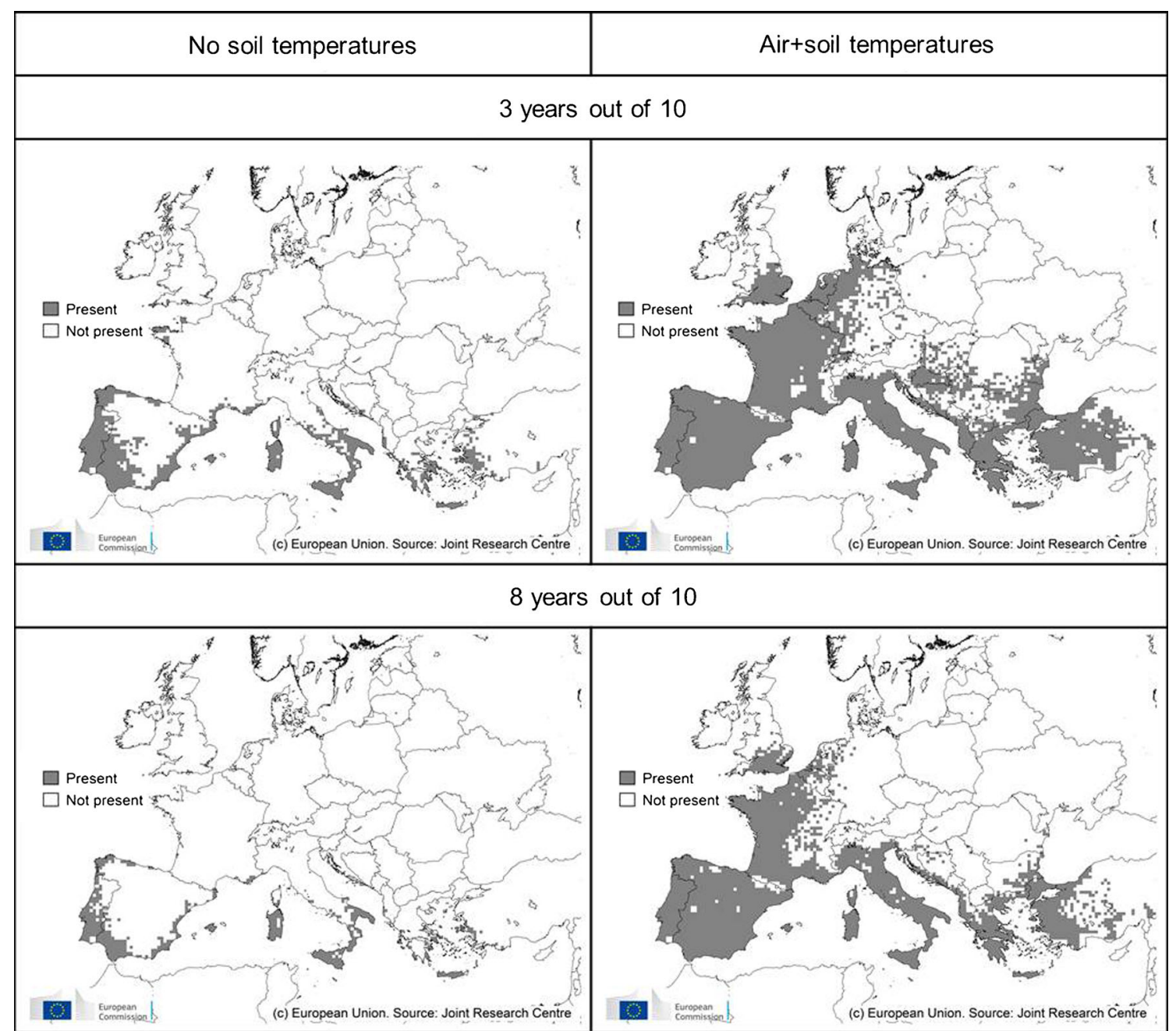

Fig. 4 Simulated potential distributions of the Mediterranean corn borer under baseline scenario (2000s). In gray, the areas where the Mediterranean corn borer is expected to survive and develop, in white areas where the Mediterranean corn borer population is expected to not survive. The maps on the left are potential distributions obtained using the AirMS approach. The maps on the right are potential distributions obtained using the SoilAirMS approach. The maps above show the areas where Mediterranean corn borer populations survived at least 3 years out of the 10 simulated. The maps below show the areas where Mediterranean corn borer populations survived at least 8 years out of the 10 simulated temperature, which is the main abiotic factor influencing insect distribution and development. Other biotic or abiotic factors were not taken into account. These factors might include a high percentage of larval population whose development is anticipated compared to the diapause induction signal of the critical photoperiod, and that consequently continue development exposing eggs to later winter temperatures (Eizaguirre and Fantinou 2012), sowing date that influence maize phenology, and the percentage of diapausing larvae (Eizaguirre et al. 2007), parasitoids (Alexandri and Tsitsipis 1990), and viruses of the Baculoviruses group reported to be endemic in the northern population of the Mediterranean corn borer (Gillyboeuf et al. 1994). This is the possible reason why the estimated potential distribution is projected as spread to some areas (Southern England and Benelux) where the Mediterranean corn borer has never been reported.
For what concerns the estimated increase in potential geographical distribution due to climate change, the potential geographical range is expected to increase according to the SoilAirMS approach including vast areas of Central and Eastern France, Belgium, The Netherlands, and Western and Northern Germany. A slight increase is also expected in the Balkans and in mainland Turkey. Since no presence of the insect is expected by the AirMS approach in these areas during the same time frame, it can be argued that uprooting and exposing the stubble on the soils surface could be a sufficient strategy to control the Mediterranean corn borer in the future in these areas of new distribution.

The main increase is expected between 2000 and 2030 (70\% of total increase between 2000 and 2050) while between 2030 and 2050 the increase is much less marked (30\% of total increase between 2000 and 2050). The noticeable 


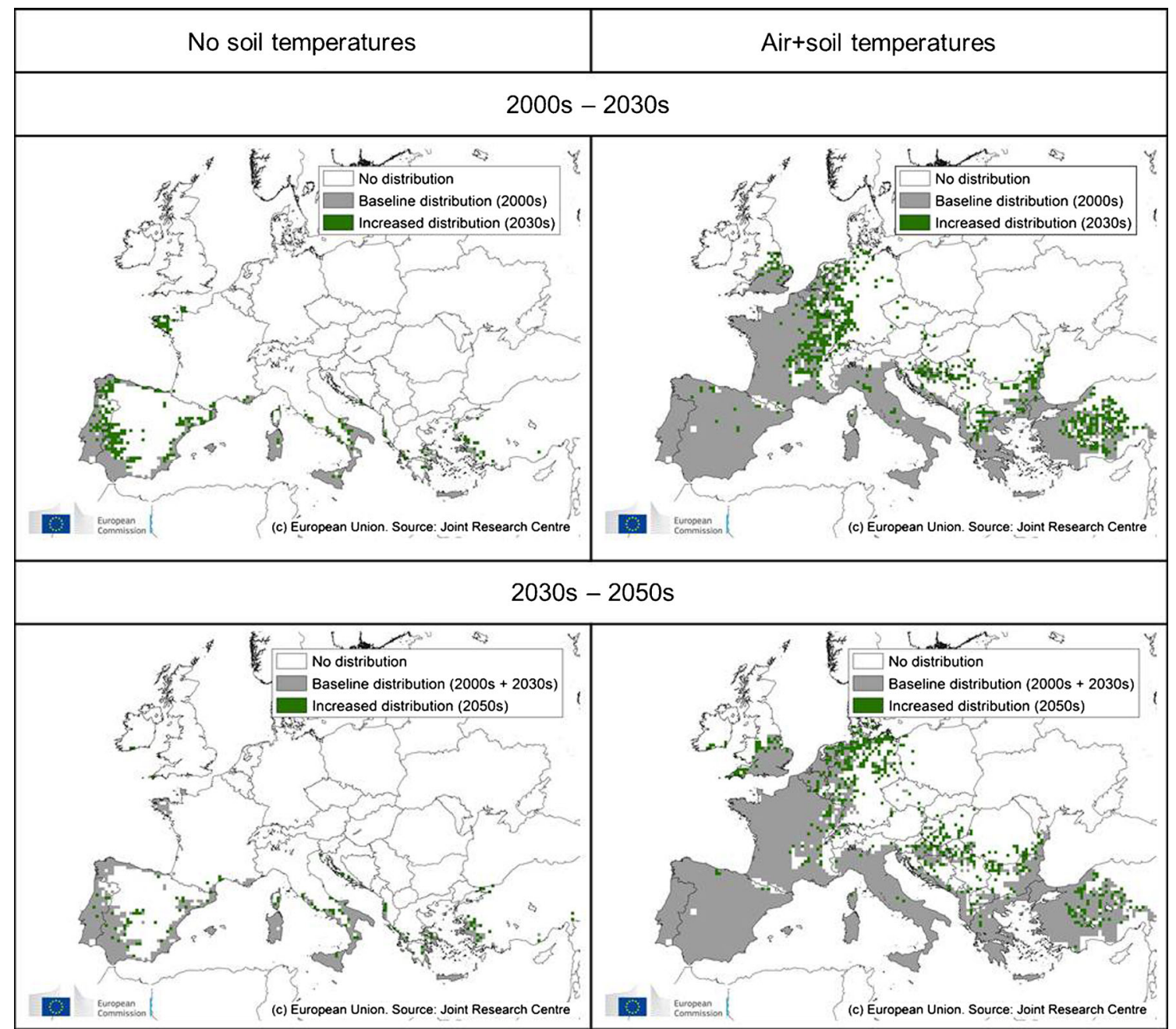

Fig. 5 Increased simulated potential distribution of the Mediterranean corn borer under 2030s and 2050s scenarios. In gray, the areas of potential distribution under baseline (2000s). In green, the areas of increased distribution under future scenarios (2030s or 2050s). The maps on the left are potential distributions obtained using the AirMS approach.

lower increase between 2030 and 2050 seems to indicate that even under rising temperature conditions, there could be a geographical limit to the expansion of the Mediterranean corn borer driven by its physiological sensitivity to temperature that could hamper the expansion of this pest, at least in the farthest time horizon considered.

\subsection{Potential phenological development under actual} and future scenarios

Results of potential phenological development of Mediterranean corn borer in Europe are shown in Fig. 6.

Results are shown in terms of absolute differences between the average potential number of generations estimated for the baseline and 2030, and between 2030 and 2050 scenarios using the SoilAirMS. The projections suggest an overall slight increase $(+0.2$ to +0.4 generations $)$ of more suitable
The maps on the right are potential distributions obtained using the SoilAirMS approach. The above maps show the increased distribution from 2000s and 2030s scenarios. The below maps show the increased distribution from 2030s and 2050s scenarios

conditions for the Mediterranean corn borer in almost all the areas where it develops under the baseline, the main increase being observed between baseline and 2030. Even if the simulated development under future scenarios suggests a slight acceleration of the Mediterranean corn borer development $(+0.2$ to +0.4 generations corresponds to an acceleration of the development of 8 to 16 days at the end of the season), this acceleration could lead to a different phenological relationship with its main host (maize) with consequences on the insect pest management strategies (Eizaguirre et al. 2007), and to a different phenological relationship with the critical photoperiod inducing diapause at the end of summer with consequences on survival and on the population levels of the Mediterranean corn borer (Gillyboeuf et al. 1994). Most of the increase $>0.6$ generations is detectable in areas where an increase in potential distribution is expected due to the absence of development during baseline. These areas that are not suitable to the 


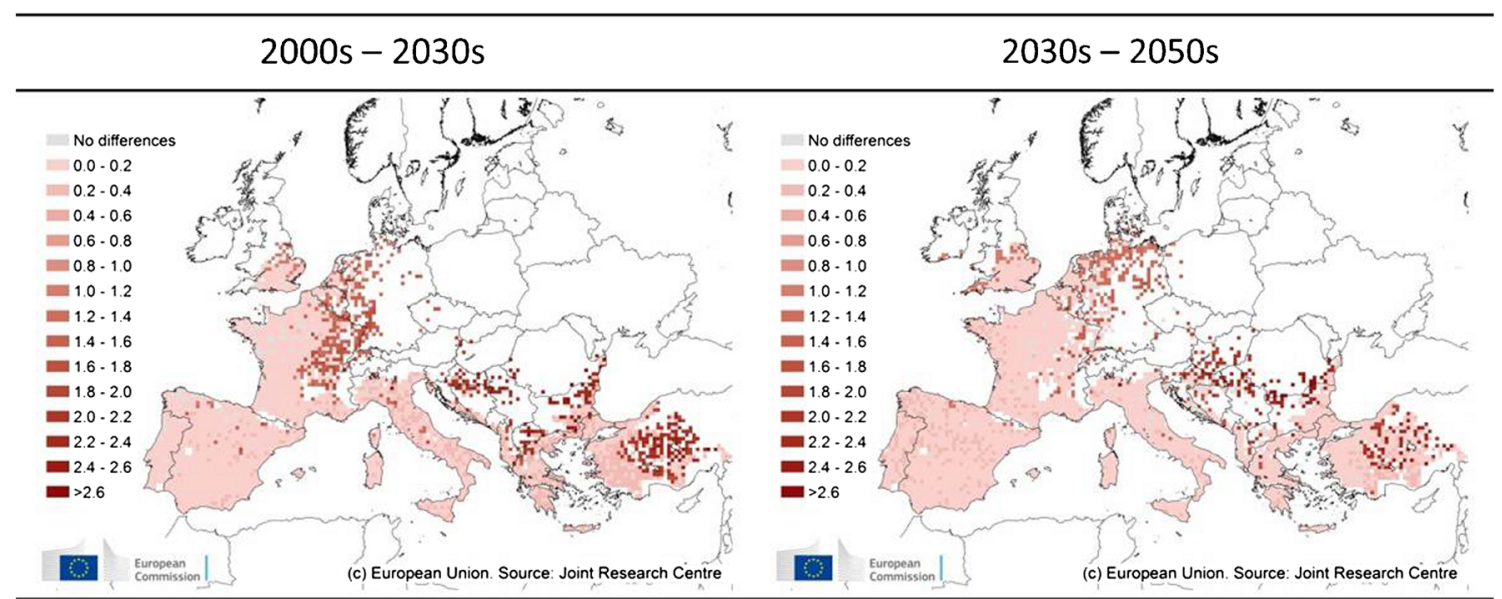

Fig. 6 Difference in the estimated number of generations per year of the Mediterranean corn borer between the 2000s and the 2030s scenario (on the left), and the 2030s and the 2050s scenario (on the right)

Mediterranean corn borer development under current climate could be interested by a significant invasion of the Mediterranean corn borer if winter conditions change. The Mediterranean corn borer could potentially develop up to two generations in France and Germany, and up to almost three in the Balkans and in mainland Turkey becoming a new insect pest in these regions with effects especially on maize productions.

\section{Conclusions}

The Mediterranean corn borer is one of the most important pests of maize in Europe. The estimation of the potential impact of climate change on its spread and development can help in evaluating risks of invasions to new areas and changes in the agronomic measures used for its control.

This is the first study about the potential survival, distribution, and phenological development of this insect pest under current and future climate considering overwinter survival in crop roots. Potential survival was simulated using an original approach based on the concept of dose exposure and taking into account the important role played by soil temperatures.

Results showed that there is a close correlation between soil temperature and the Mediterranean corn borer distribution. Even if most of the larvae overwinter above the soil surface, the Mediterranean corn borer potential distribution was much better explained when soil temperature was taken into account (SoilAirMS approach). On the contrary, the modeling approach without soil temperature as input (AirMS) largely underestimated the insect distribution compared to the observed one. Nevertheless, the AirMS approach was also useful as it allowed identifying areas where the Mediterranean corn borer winter survival is assured even without the soil thermal buffer. In these areas, overwintering larvae can survive on the soil surface and the agronomic strategy usually suggested for $S$. nonagrioides control would not be effective. This practice consists in uprooting and exposing the stubble on the soils surface for exposing larvae to winter cold.

Potential distribution under future scenarios close to present allowed identifying areas of future potential invasion by the Mediterranean corn borer. Simulation results suggested that in these areas the rising of winter soil temperatures could create the potential conditions for the onset of this insect pest. In these regions, the Mediterranean corn borer could become an important pest as the temperatures during the development season could allow the development of up to three generations. In these areas, exposing the root to air temperature could be a very effective measure.

For what that concern changes in phenological development under future climate scenarios, they could be very limited and might not lead to changes in the number of observed generations in the areas where this insect is spread under current conditions. Nevertheless, these small changes could change the phenological relationships between the Mediterranean corn borer and maize, and between the Mediterranean corn borer and the critical photoperiod inducing diapause at the end of summer. These changes might have effects on population levels.

Further simulation studies are needed (1) to evaluate the impact of the new phenological relationships with the critical photoperiod at the end of summer, (2) using other different climate projections in order to evaluate the Mediterranean corn borer distribution and development estimation uncertainty, and (3) to understand how the phenological relationships between the insect and its main host could change under a warming climate. This can be done coupling MIMYCS.Borers to maize crop development simulations. Thanks to the implementation technology used for developing the modeling approaches 
presented in this paper, such studies and improvements can be easily performed.

Acknowledgments This research was supported by a Marie Curie Intra European Fellowship within the 7th European Community Framework Programme and partially supported by the project AgroScenari of the Italian Ministry of Agricultural, Food and Forestry Policies. Thanks to Raúl López Lozano (EC-JRC) for his help with some mapping-related issues.

\section{References}

Albajes R, Konstantopoulou M, Etchepare O et al (2002) Mating disruption of the corn borer Sesamia nonagrioides (Lepidoptera: Noctuidae) using sprayable formulations of pheromone. Crop Prot 21:217-225. doi:10.1016/S0261-2194(01)00088-6

Alexandri MP, Tsitsipis JA (1990) Influence of the egg parasitoid Platytelenomus busseolae [Hym.: Scelionidae] on the population of Sesamia nonagrioides [Lep.: Noctuidae] in central Greece. Entomophaga 35:61-70. doi:10.1007/BF02374302

Andreadis SS, Vryzas Z, Papadopoulou-Mourkidou E, SavopoulouSoultani M (2011) Cold tolerance of field-collected and laboratory reared larvae of Sesamia nonagrioides (Lepidoptera: Noctuidae). CryoLetters 32:297-307

Avantaggiato G, Quaranta F, Desiderio E, Visconti A (2003) Fumonisin contamination of maize hybrids visibly damaged by Sesamia. J Sci Food Agr 83:13-18

Bale JS, Hayward AL (2010) Insect overwintering in a changing climate. J Exp Biol 213:980-994

Bayram A, Gültekin A, Bruce TJ, Gezan S (2007) Factors associated with mortality of the overwintering generation of Sesamia nonagrioides under field conditions. Phytoparasitica 35:490-506. doi:10.1007/ BF03020608

Boselli F (1959) Un nuovo importante parassita del riso in Sardegna: la perforatrice dei culmi Sesamia nonagrioides (Lef.) Tams (Lep. Noctuide). Annali di Sperimentazione Agraria (Nuova Serie) (IT) 13:47-49

Curry GL, Feldman RM (1987) Mathematical foundations of population dynamics. Texas A\&M University Press, Texas University, College Station

Delgado de Torres D (1929) Las orugas del maìz. Bol Patol Veg Entomol Agric (SP) 4:1-20

Diffenbaugh NS, Krupke CH, White MA, Alexander CE (2008) Global warming presents new challenges for maize pest management. Environ Res Lett 3:044007. doi:10.1088/1748-9326/3/4/044007

Dimou I, Pitta E, Angelopoulos K (2007) Note: Corn stalk borer (Sesamia nonagrioides) infestation on sorghum in central Greece. Phytoparasitica 35:191-193. doi:10.1007/BF02981113

Donatelli M, Rizzoli AE (2008) A design for framework-independent model component of biophysical systems. In: Sànchez-Marrè M, Béjar J, Comas $\mathrm{J}$ et al (eds) International Congress on Environmental Modelling and Software. Integrating Sciences and Information Technology for Environmental Assessment and Decision Making. iEMSs, Barcelona, pp 727-734

Donatelli M, Carlini L, Bellocchi G (2006) A software component for estimating solar radiation. Environ Modell Softw 21:411-416. doi: 10.1016/j.envsoft.2005.04.002

Donatelli M, Bellocchi G, Habyarimana E et al (2010) AirTemperature: extensible software library to generate air temperature data. SRX Comput Sc 2010:1-8. doi:10.3814/2010/812789

Donatelli M, Fumagalli D, Zucchini A et al (2012) A EU 27 database of derived daily weather data from climate change scenarios for use with crop simulation models. In: Seppelt R, Voinov A, Lange S, Bankamp D (eds) iEMSs 6th International Congress-Managing Resources of a Limited Planet: Pathways and Visions under Uncertainty. iEMSs, Leipzig, pp 868-875

Dosio A, Paruolo P (2011) Bias correction of the ENSEMBLES highresolution climate change projections for use by impact models: Evaluation on the present climate. J Geophys Res 116:D16106. doi:10.1029/2011JD015934

Eizaguirre M, Fantinou AA (2012) Abundance of Sesamia nonagrioides (Lef.) (Lepidoptera: Noctuidae) on the Edges of the Mediterranean Basin. Psyche 2012:1-7. doi:10.1155/2012/854045

Eizaguirre M, López C, Sans A (2007) Maize phenology influences field diapause induction of Sesamia nonagrioides (Lepidoptera: Noctuidae). Bull Entomol Res 92:439-443. doi:10.1079/ BER2002183

ENDURE (2010) Final report on the maize case study: key pests and options to reduce pesticides in eleven European regions. Project ENDURE, Deliverables DR3.7, DR1.18 \& DR1.19, http://www. endure-network.eu/content/download/5458/42972/file/ENDURE_ DR3.7\&DR1.18\&DR1.19.pdf, Accessed 4 September 2013

Fantinou AA, Chourdas MT (2005) Thermoperiodic effects on larval growth parameters of the Sesamia nonagrioides (Lepidoptera: Noctuidae). J Pest Sci 79:43-49. doi:10.1007/s10340-005-0107-4

Fantinou AA, Chatzoglou CS, Kagkou A (2002) Thermoperiodi effects on diapause of Sesamia nonagrioides (Lepidoptera: Noctuidae). Eur J Entom 99:421-425

Fantinou AA, Perdikis DC, Zota KF (2004) Reproductive responses to photoperiod and temperature by diapausing and nondiapausing populations of Sesamia nonagrioides Lef. (Lepidoptera-Noctuidae). Physiol Entomol 29:169-175. doi:10.1111/j.1365-3032.2004. 00381.x

Farinós GP, Andreadis SS, de la Poza M et al (2011) Comparative assessment of the field-susceptibility of Sesamia nonagrioides to the $\mathrm{Cry} 1 \mathrm{Ab}$ toxin in areas with different adoption rates of $\mathrm{Bt}$ maize and in Bt-free areas. Crop Prot 30:902-906. doi:10.1016/j.cropro. 2011.03.011

Figueiredo D, Araujo J (1990) Introdução à protecção integrada da cultura do milho de regadio. Bol San Veg Plagas 16:135-138

Finney DJ (1971) Probit analysis. University Press, Cambridge [Eng.]

Germinara GS, Rotundo G (2011) Attrattività di composti volatili di origine vegetale verso gli adulti di Sesamia nonagrioides (Lepidoptera, Noctuidae). Proceedings of the XXIII Italian Congress of Entomology, Genova. Available at: http:// entomologia2011.comune.genova.it/Atti\%20XXIII\%20CNIE\% 20(Genova,\%2013-16.VI.2011).pdf. Accessed 4 September 2013. p 151

Gillyboeuf N, Anglade P, Lavenseau L, Peypelut L (1994) Cold hardiness and overwintering strategy of the pink maize stalk borer, Sesamia nonagrioides Lef(Lepidoptera, Noctuidae). Oecologia 99:366-373. doi:10.1007/BF00627750

Gutierrez AP, Ponti L, Gilioli G (2010) Climate change effects on plantpest-natural enemy interactions. In: Daniel H, Cynthia R (eds) Handbook of climate change and agroecosystems: impacts, adaptation, and mitigation. Imperial College Press, London, pp 209-237

Hilal A (1981) Etude du développement de Sesamia nonagrioides et établissement de modèles pour la prévision de ses populations dans la nature. EPPO Bulletin 11:107-112. doi:10.1111/j.1365-2338. 1981.tb01775.x

Kavut H (1987) Ege Bölgesi misirlarinda zarar yapan Misir Koçan Kurdu (Sesamia nonagrioides Lef. Lepidoptera: Noctuidae)' nun mücadelesine esas bazi biyolojik bulgular (Eng: Some biological investigations relating with control of corn stalk borer (Sesamia nonagrioides Lef.) which harmful on corn in Aegean Region. Türkiye Entomoloji Kongresi, 13-16 October 1987, Izmir. Bornova/Izmir, Turkey, pp. 157-166. Available at: http:// entomoloji.ege.edu.tr/files/Kongreler/Ento_1/Ento_1_157-166.pdf 
Leniaud L, Audiot P, Bourguet D et al (2006) Genetic structure of European and Mediterranean maize borer populations on several wild and cultivated host plants. Entomol Exp App 120:51-62. doi: 10.1111/j.1570-7458.2006.00427.x

López C, Sans A, Asin L, EizaGuirre M (2001) Phenological model for Sesamia nonagrioides (Lepidoptera: Noctuidae). Environ Entomol 30:23-30. doi:10.1603/0046-225X-30.1.23

Maiorano A, Bregaglio S, Donatelli M et al (2012) Comparison of modelling approaches to simulate the phenology of the European corn borer under future climate scenarios. Ecol Model 245:65-74. doi:10.1016/j.ecolmodel.2012.03.034

Mazur P (1984) Freezing of living cells: mechanisms and implications. Am J Physiol 247:C125-C142

Mendes C (1913) Lepidopteros mais daninhos á agricultura nos arredores de S. Fiel. Brotér, Sér Zool (PR) 11:40-44

Novillo C, Fernández-Anero FJ, Costa J (2003) Resultados en España con variedades de maíz derivadas de la línea MON 810, protegidas genéticamente contra los taladros. Bol San Veg Plagas 29:427-439

Nucifora A (1966) Appunti sulla biologia di Sesamia nonagrioides (Lef.) in Sicilia. Tecnica Agricola (IT) 18:395-419
Porcelli F, Parenzan P (1993) Damage by Opogona sacchari and Sesamia nonagrioides to Strelitzia in southern Italy. Informatore Fitopatologico (IT) 43:21-24

Régnière J (2009) Predicting insect continental distributions from species physiology. Unasylva 60:37-42

Régnière J, Logan JA (2003) Animal life cycle models. In: Schwartz M (ed) Phenology: an integrative environmental science. Kluwer, Dordrecht, pp. 237-254

Trnka M, Muska F, Semeradova D et al (2007) European corn borer life stage model: regional estimates of pest development and spatial distribution under present and future climate. Ecol Model 207:61-84

Velasco P, Revilla P, Monetti L et al (2007) Corn borers (Lepidoptera: Noctuidae; Crambidae) in northwestern Spain: population dynamics and distribution. Maydica 52:195-203

Vincent K (2013) Probit analysis. Available from: http://userwww.sfsu. edu/ efc/classes/biol710/probit/ProbitAnalysis.pdf, Accessed 19 August 2013

Yan W, Hunt LA (1999) An equation for modelling the temperature response of plants using only the cardinal temperatures. Ann Bot 84:607-614. doi:10.1006/anbo.1999.0955 